Pamiętnik Literacki 2018, 3, s. 189-204

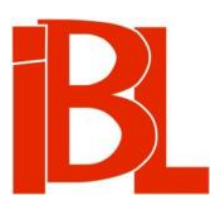

\title{
Cień Jasieńskiego. Przyczynek biobibliograficzny
}

Wojciech Tomasik 
Pamiętnik Literacki CIX, 2018, z. 3, PL ISSN 0031-0514

DOI: $10.18318 / \mathrm{pl} .2018 .3 .12$

WOJCIECH TOMASIK Uniwersytet Kazimierza Wielkiego, Bydgoszcz

\section{CIEŃ JASIEŃSKIEGO PRZYCZYNEK BIOBIBLIOGRAFICZNY}

Bruno Jasieński był pisarzem dwujęzycznym ${ }^{1}$. Na jego wcale pokaźny dorobek literacki składa się kilkadziesiąt pozycji autorskich i jedna współautorska. Te pierwsze są na ogół dobrze znane i dostępne w formie licznych edycji, inaczej rzecz przedstawia się $\mathrm{z}$ tekstem, w którym Jasieński wystapił w kolektywie: przez ponad 60 lat był to biblioteczny „biały kruk” - wiedziało o nim stosunkowo niewielu. Dziś paradoksalnie - stał się on osiagalny dla odbiorców na całym świecie, można go odszukać i przeczytać na stronie internetowej, gdzie od dłuższego czasu zawieszony jest reprint wydania książkowego ${ }^{2}$. Ta łatwa dostępność nie znalazła jednak dotąd odzwierciedlenia w notach biobibliograficznych. W zestawieniach utworów Jasieńskiego wciąż pomija się Biełomorsko-Bałtijskij kanat imieni Stalina (Kanał Białomorsko-Bałtycki imienia Stalina) ${ }^{3}$. A o samym współautorstwie pisze się zwykle w tonie

Zob. E. B a l c e r z a n: Styl i poetyka twórczości dwujęzycznej Brunona Jasieńskiego. Z zagadnień teorii przekładu. Wrocław 1968; wstęp w: B. J a sieńs ki, Utwory poetyckie, manifesty, szkice. Oprac. E. Balcerzan. Wrocław 1972.

2 Biełomorsko-Battijskij kanat imieni Stalina. Istorija stroitielstwa, 1931-1934 gg. [Kanał Białomorsko-Bałtycki imienia Stalina. Historia budowy, 1931-1934]. Ried. M. G orkij, L. Awi er ba ch, S. Firi n. B.m., 1998 (reprint wyd. z r. 1934). Wersja elektroniczna, umieszczona na ogólnodostępnej stronie internetowej: http://www.e-reading.mobi/bookreader.php/1025843/Gorkiy_-_Belomorsko-baltiyskiy_kanal_imeni_Stalina.html, jest marnej jakości, bez paginacji, ze sporą ilością błędów, powstałych prawdopodobnie przy skanowaniu egzemplarza papierowego. Do niej wszakże ze względu na łatwy dostęp - będę się w artykule odwoływać (jeśli nie zaznaczę inaczej), posługując się tytułem: Historia, stanowiącym de facto początek podtytułu. Czynię to dla wygody - odstępując tu od zasad edytorskich, zalecających używanie tytułu oryginalnego, jeśli tekst nie był wydany po polsku - stosowanie bowiem tytułu Biełomorsko-Bałtijskij kanał imienii Stalina w rozmaitych uwikłaniach składniowych stwarzałoby problemy deklinacyjne. Analogicznie postępuję z tytułami rozdziałów i podrozdziałów: podaję je w swoim tłumaczeniu, zapisując kursywą, tak jakby to były tytuły „oficjalne”, czyli pochodzące z publikacji w języku polskim.

Rozdział 9, który będę badał, to w reprincie s. 361-404.

3 Zob. A. Sz. [A. Szała g a n]: Jasieński Bruno. Hasło w: Wspótcześni polscy pisarze i badacze literatury. Stownik biobibliograficzny. T. 3: G-J. Warszawa 1994; Jasieński Bruno. Hasło w: Wspótcześni polscy pisarze $i$ badacze literatury. T. 10: $\dot{Z}$ i uzupetnienia do tomów 1-9. Warszawa 2007. Zob. też Bruno Jasieński. Oprac. T. B uj ni cki. Bibliografię oprac. I. J a ro s iń s ka. W zb.: Literatura polska $w$ okresie międzywojennym. T. 3. Zespół redakcyjny: I. M a ciejewska, J. Trznade1, M. Pokrasenowa. Kraków 1993 (na stronie redakcyjnej widnieje adnotacja: „Redakcję tomu ukończono w 1987 roku”). „Obraz Literatury Polskiej XIX i XX Wieku”. Seria 6. O współautorstwie Jasieńskiego w Historii nie wspomina kanadyjska slawistka N. Kole s n i k off w monografii Bruno Jasieński. His Evolution from Futurism to Socialist Realism (Waterloo, Ont., 1982). 
kąśliwej publicystyki ${ }^{4}$. Taki ton był w pełni zrozumiały w narracji prowadzonej przez Aleksandra Sołżenicyna, który bodaj jako pierwszy przypomniał związki Historii z nazwiskiem Jasieńskiego. W Archipelagu GUŁag pisał z ironią o księdze „formatu niemal tak wielkiego jak mszał" i rozwijał to porównanie słowami:

Księga była niejako po to, by przetrwać wieki, by potomność czytała ją z nieustającym podziwem. Ale fatalny zbieg okoliczności sprawił, że większość przywódców, sławionych w niej i uwiecznionych na fotografiach, miała zostać w ciągu najbliższych 2-3 lat zdemaskowana jako zgraja wrogów ludu. Zrozumiałe, że cały nakład tej książki został usunięty z bibliotek i oddany na przemiał ${ }^{5}$.

Dla literaturoznawcy szczególnie interesujący jest fragment z nazwiskami:

Słuszne też będzie, jeśli zachowają się w historii literatury imiona jej autorów. Choćby takie: Maksym Gorki - Wiktor Szkłowski - Wsjewołod Iwanow - Wiera Inber - Walenty Katajew - Michał Zoszczenko - Łapin i Chacrewin - Lew Nikulin - Kornel Zielinski - Bruno Jasieński (rozdział Dobijmy wroga klasowego) - Konstanty Finn ${ }^{6}$.

Dwie rzeczy muszą tu zwracać uwagę. Pierwsza rzuca się w oczy natychmiast: tylko przy nazwisku Jasieńskiego pada tytuł rozdziału, który w zbiorowej Historii pisarz współtworzył. Żeby zauważyć drugą osobliwość wyliczenia, trzeba wziąć do ręki reprint lub rzucić okiem na stronę internetowa, na której został on udostępniony. Okaże się wtedy, że na liście Sołżenicyna znaleźli się prawie wszyscy współautorzy rozdziału zatytułowanego Dobić wroga klasowego.

Uporządkujmy podstawowe fakty ${ }^{7}$. Kanał łączaccy Morze Białe $z$ Bałtykiem budowany był rękami (dosłownie!) setek tysięcy więźniów. To pierwsze tego typu przedsięwzięcie wkrótce powtórzone zostało na dziesiątkach budów w całym Związku Sowieckim, gdzie mordercza prace (w skrajnie trudnych warunkach i z minimalnym wykorzystaniem maszyn) wykonywali więźniowie $z$ „archipelagu GUŁag”. Liczacy ponad $200 \mathrm{~km}$ Kanał Białomorsko-Bałtycki przekopano w ciagu niespełna dwóch lat, jego oficjalne otwarcie nastapiło w maju 1933, w lipcu gotowy Kanał wizytował Stalin w towarzystwie Woroszyłowa i Kirowa. W połowie sierpnia 1933 władze zorganizowały wyjazd na ten teren 120 pisarzy, którzy poznać mieli Kanał i udokumentować go w zbiorowej publikacji. Cele, jakim miała ona służyć, zostały jasno określone. Chodziło o pokazanie sukcesów państwa zarówno w sferze gospodarki, jak i edukacji. Sukces gospodarczy ilustrowały najlepiej mapy z naniesionym przebiegiem nowej drogi wodnej, a zadaniem pisarzy było takie mapy ideologicznie skomentować. W budowie Kanału realizować się też powinna fundamentalna zasada pedagogiki sowieckiej, zgodnie $\mathrm{z}$ którą w procesie kolektywnej pracy człowiek

4 Zob. T. Kizy (współpr. T. Ko s in ow a), Biełomorkanał imienia Stalina. „Karta” 1994, nr 13, s. 87. - K. Ma słoń, Bruno Jasieński: pisarz polski czy kacapski? „Uważam Rze. Historia” 2012, nr 8. Temu stylowi pisania o współautorstwie Jasieńskiego uległ, niestety, także K. J a w o r s k i, autor monografii Dandys. Słowo o Brunonie Jasieńskim (Warszawa 2009, s. 219-220).

5 A. Sołżeni cy n, Archipelag GUŁag 1918-1956. Próba dochodzenia literackiego. Autoryzowany przekł. z rosyjskiego J. Po mianows ki (M. Ka ni ow ski). T. 2. Warszawa 1990, s. 71.

$6 \quad$ Ibidem, s. 72. W oryginale książki Sołżenicyna (jej pierwsze wydanie wyszło w Paryżu w 1970 r.) przywołany tytuł rozdziału brzmi (zgodnie z prawdą): Dobić wroga klasowego.

$7 \quad$ W tym porządkowaniu wykorzystywać będę wiedzę, którą dają: S o ł ż e n i c y n, op. cit., s. 71-98. C. A. Ruder, Making History for Stalin. The Story of the Belomor Canal. Gainesville 1998. - A. A p pelba u m, GUŁAG. Przeł. J. U rbań s ki. Warszawa 2005, rozdz. 4: Kanał Białomorski. F. W e s terma n, Inżynierowie dusz. Przel S. Paszki et, Warszawa 2007, rozdz. Biełomor. 
zmienia siebie. Dla tysięcy więźniów zatrudnionych przy kopaniu nowej drogi wodnej zespołowy wysiłek miał służyć do zapewnienia im godnego powrotu do społeczeństwa. Zakładano, iż postępom w budowie będzie towarzyszyć „przekuwanie” („pieriekowka”) charakterów: $z$ kryminalistów i „wrogów ludu” rodzili się świadomi obywatele sowieccy, „nowi ludzie”. W ciągu kilku miesięcy 1933 r. zespół 36 pisa$\mathrm{rzy}^{8}$ przygotował tom zatytułowany Biełomorsko-Bałtijskij kanat imieni Stalina. Istorija stroitielstwa, 1931-1934 gg. Egzemplarze pierwszego wydania wręczone zostały w styczniu 1934 delegatom na XVII Zjazd WKP(b) (tzw. Zjazd Zwycięzców). W kilka tygodni później ukazało się drugie (skromniejsze edytorsko, ale o znacznie wyższym nakładzie), w 1935 r. zaś wyszło trzecie ${ }^{9}$. W tym samym roku nowojorska oficyna Harrison Smith and Robert Haas wypuściła na rynek angielski przekład (znacznie zmieniony): Belomor ${ }^{10}$. W roku 1937 fala „wielkiej czystki” dotknęła inicjatorów i współautorów Historii. O konsekwencjach tego dla sowieckich egzemplarzy wspomniał cytowany Sołżenicyn: po 1937 r. można było je odnaleźć tylko w prywatnych zbiorach. Po blisko 60 latach niebytu Historia wróciła jednak do czytelnika, przypomniana przez reprint, którego dokonało anonimowe rosyjskie wydawnictwo. Od dłuższego czasu reprint ten trafia do zainteresowanych łatwiej niż jakakolwiek postać papierowa: jest zawieszony na ogólnodostępnej stronie internetowej.

To zupełnie podstawowe fakty, których zebranie nie przedstawia dziś szczególnych trudności. Ale jeśli interesuje nas wkład Jasieńskiego w Historię, ta porcja wiedzy nie wnosi niczego do stanu, który wyłania się $z$ narracji Sołżenicyna. Żeby powiedzieć coś więcej, trzeba wziąć do ręki rosyjski reprint (lub skorzystać z jego internetowej wersji), warto sięgnąć też po kuriozalny angielski przekład (Belomor wciąż jest oferowany za nieduże pieniądze w wielu internetowych księgarniach ${ }^{11}$ ) i dobrze jest zanurzyć się w archiwaliach. $Z$ tym ostatnim jest zdecydowanie najgorzej. Doskonale wiadomo, że informacje o okolicznościach powstawania Historii

8 W przedsięwzięcie zaangażowani zostali także plastycy, w tym (o czym wspomina się rzadko) Aleksander Rodczenko, autor włączonych do księgi fotografii, i Aleksander Deineka, współodpowiedzialny za stronę plastyczną. Rodczenko na terenie budowy zrobił ponad 2000 zdjęć, kilkanaście z nich trafiło do tomu Historii. Zob. A. Lavrenti ev, Alexander Rodchenko. Photography 19241954. Köln 1995, s. 26-27, 240-145 (zdjęcia), 337.

9 Zob. Ruder, op. cit., s. 86-87.

10 Zob. Belomor. An Account of the Construction of the Canal Between the White Sea and the Baltic Sea. Ed. M. Gorky, L. Au erbach, S. G. Firin. [...] Prepared from the Russian and edited, with a Special Introduction, by A. W illi a m s - Elli s. New York 1935. O stosunku tego „przekładu” do oryginału wyczerpująco pisze Ruder (op. cit., s. 192-203), nazywając pracę anonimowych tłumaczy „pieriekowką [reforging]” i dodając, że powstały tekst „sabotuje integralność oryginału” (s. 193). Niestety, Westerman (op. cit.) odbył swoja podróż na teren Kanału, obdarzając pełnym zaufaniem angielski tekst-„,sabotaż”. Fragment angielskiego przekładu funkcjonuje dziś także w przedruku: The Stalin White Sea - Baltic Canal. W zb.: Mass Culture In Soviet Russia. Tales, Poems, Songs, Movies, Plays and Folklore, 1917-1953. Ed. J. vo n G eld er n, R. Stite s. Bloomington 1995. Edytorzy tego tomu doliczyli się 37 autorów Historii - do 34 autorów (oryginalna ich lista uszczuplona została o dwa nazwiska) dodali trzech redaktorów, zapominając, że nazwisko Gorkiego figuruje w obu porządkach.

11 Kto czytał Belomor, gdy się ukazał w USA? Ktoś chyba jednak czytał. Mój egzemplarz ma odręczną notatkę: „Sylvia Gittlen, Dec[ember] 1939”. Sylvia Gittlen dostała książkę, gdy miała 20 lat. Rok później posiadaczka mego egzemplarza wyszła za mąż i stała się panią Gittlen Krissoff, jeszcze później zrobiła kariere jako historyczka sztuki. 
kryja się w rosyjskich kompleksach archiwalnych, ale każdy, kto kiedykolwiek spróbował do nich dotrzeć, przekonał się, o jak trudne tu chodzić może przedsięwzięcie. Kanał miał wątłe uzasadnienie ekonomiczne, trzeba wszakże pamiętać, iż $\mathrm{w}$ wielu sowieckich inwestycjach za interesem gospodarczym stał jeszcze interes militarny. Pierwszy był propagandowo mocno nagłaśniany, drugi - utrzymywany w ścisłej tajemnicy. A Kanał, jak pokazują współcześni historycy, miał dawać Związkowi Sowieckiemu większą mobilność floty wojennej, która mogłaby być przerzucana $z$ Bałtyku na Atlantyk (i na odwrót), z pominięciem łatwych do zablokowania cieśnin duńskich ${ }^{12}$. To oznacza wszakże, że budowa realizowana przez białomorsko-bałtycki oddział GUŁagu wytwarzała dokumentację, gdzie to, co najciekawsze dla historyka, zaplombowane zostało najpieczołowiciej. Otwarcie niewielkiej części rosyjskich archiwów pozwoliło wszakże amerykańskiej rusycystce, Cynthii A. Ruder, dotrzeć do dokumentów pokazujących, jak powstawała Historia. Badaczka mało pisze o udziale Jasieńskiego, ale zamieszcza w swej monografii bardzo dużo materiału, z którego udział ten można w najogólniejszych zarysach zrekonstruować. Jeśli dodamy, że łatwo dostępny jest rosyjski tekst i jego angielski (niby-)przekład, sytuacja historyka literatury zainteresowanego publikacją poświęconą budowie Kanału oraz Jasieńskim wydać się musi komfortowa. Bo trzy wspomniane źródła pozwalają znacząco wzbogacić szkicowaną wcześniej faktografię.

Zaczać wypada od wyjazdu pisarzy w sierpniu 1933. Uczestniczyło w nim 120 osób, Cynthii A. Ruder udało się zidentyfikować nieco ponad połowę z nich. Mamy zatem listę 66 nazwisk tych, którzy pojechali oglądać uruchomiony Kanał ${ }^{13}$. Jest na niej Bruno Jasieński, ostatni $z$ wymienionych, bo autorka posłużyła się porządkiem alfabetu rosyjskiego.

Lista zasługuje na parę komentarzy. Po pierwsze, unaocznia, iż w wyprawie tej nie uczestniczył Maksim Gorki, który do tomu napisał rozdział 1 (Prawda socjalizmu) i zamykający całość rozdział 15 (Pierwsze doświadczenie) ${ }^{14}$. Po drugie, w kolektywie zwiedzajacych Kanał nie było Wiktora Szkłowskiego (który oglądał budowe wcześniej, jako korespondent „Pogranicznika”) i Siergieja Ałymowa (który poznał budowę jako więzień i zarazem redaktor naczelny wydawanej tam gazety „Pieriekowka") ${ }^{15}$. Po trzecie, w wyprawie wzięła udział Anna Bierzin, prywatnie - nowa żona Jasieńskiego, co oznaczało, iż Jasieńscy potraktowani zostali zupełnie wyjąt-

Zob. M. Morukov, The White Sea-Baltic Canal. W zb.: The Economics of Forced Labor. The Soviet Gulag. Ed. P. R. Gre gory, V. V. Lazarev. Stanford 2003, s. 161-162.

Ru d e r, op. cit., s. 213-214.

Warto o tym wspomnieć, bo w literaturze przedmiotu pojawiają się inne sądy. A p p elb a u m (op. cit., s. 88) pisze - dla przykładu - że „Gorki zabrał na podobną wyprawę [tj. nad świeżo otwarty Kanał] 120 pisarzy sowieckich”, co sugeruje wyraźnie obecność w zespole inicjatora i redaktora tomu. Niejasno wypowiada się na ten temat W e s te r m a n (op. cit., s. 54), gdy stwierdza, że „latem 1933 roku Gorki zestawił listę stu dwudziestu pisarzy, których zaprasza na przejażdżkę po gułagach”. Jak ustaliła Ruder, wybór uczestników wyjazdu nie był decyzją Gorkiego. Nb. oprócz Gorkiego jako samodzielny autor rozdziału w Historii wystąpił tylko M. Zos z c ze n k o (12: Historia jednej „pieriekowki”).

Zob. Ruder, op. cit., s. 54-59. Szkłowski był na budowie w okresie od 6 do 10 X 1932 . Pobyt posłużył mu do zbierania materiałów do „Pogranicznika” (i innych artystycznych projektów). A prywatnie - do asystowania przy zwolnieniu z białomorskiego obozu brata, Władimira (wybitnego leksykografa). Ałymow zwolniony został i powrócił do Moskwy po zakończeniu budowy, tj. latem 1933. 
kowo. Na inną wyjątkowość zwrócił uwagę Sołżenicyn: Jasieński był spośród 120 osób jedynym pisarzem niesowieckim, dlatego prawdopodobnie w Archipelagu GUŁag tylko przy jego nazwisku znalazło się wskazanie na tytuł rozdziału z Historii (Dobić wroga klasowego).

Łatwe do ustalenia są też fakty związane $\mathrm{z}$ autorskim udziałem $\mathrm{w}$ tomie. A więc ten, że lista współautorów pierwszego rosyjskiego wydania obejmowała 36 pisarzy, lista zaś w angielskim (niby-)przekładzie liczy 34 nazwiska ${ }^{16}$. Jako redaktorzy całości figuruja w wydaniach rosyjskim i angielskim ci sami: Maksim Gorki, Leopold Awierbach i Siemion Firin. W rosyjskiej edycji mamy wykaz rozdziałów z przyporządkowanymi im nazwiskami współautorów (wymienianych alfabetycznie). Jasieński, jak już wiemy, jest odnotowany przy rozdziale 9. Oprócz niego pojawia się tutaj pięć innych nazwisk. To (kolejno, według rosyjskiego alfabetu): Boris Agapow, Korniel Zielinski, Wsiewołod Iwanow, Wiera Inbier, Zachar Chacriewin. Czterech z nich współuczestniczy w innych rozdziałach Historii: Agapow w dwóch (8: Tempo i jakość, i 11: Wiosna sprawdza kanał), Iwanow w sześciu (4: Więźniowie, 5: Czekiści, 8, 10: Szturm oddziału wodnego, 11 i 13: Imienia Stalina), Inbier w trzech (4, 11 i 14: Towarzysze), Chacriewin w dwóch (4 i 6: Ludzie zmieniaja zawód). Współautorstwo Zielinskiego, tak jak Jasieńskiego, odnotowane zostało tylko przy jednym rozdziale. Anna Bierzin uczestniczyła w pisaniu aż czterech rozdziałów. Jej nazwisko zjawia się przy rozdziałach 5, 6,7 (Kanałoarmiści) i 11. Angielski (niby-)przekład daje atrybucję tylko w odniesieniu do całości tomu. Na liście 34 pisarzy-współautorów są nazwiska Bierzin i Jasieńskiego (jako „A. Berzin” i „B. Yassensky”).

Każdy z 15 rozdziałów rosyjskiego pierwodruku składa się z mniejszych części. Nie mają one jednak żadnych autorskich identyfikatorów. Sprawę przyporządkowania poszczególnych fragmentów do konkretnych nazwisk komplikuje przyjęta „metoda twórcza”. W rosyjskim oryginale czytamy we wstępnych (niesygnowanych) uwagach:

Za tekst książki odpowiadają wszyscy autorzy. Pomagali sobie wzajemnie, uzupełniali się, poprawiali. Dlatego wskazanie indywidualnego autorstwa było nierzadko kłopotliwe. Podajemy tutaj autorów głównych części, wchodzących w ten czy inny rozdział, jeszcze raz przypominając, że faktycznym autorem całej księgi jest pełen zespół pracujących nad historią budowy Kanału Białomorsko-Bałtyckiego imienia Stalina.

\section{Angielski (niby-)przekład otwiera inna deklaracja:}

Wszyscy z 34 autorów biorą pełną odpowiedzialność za tekst. Wszyscy pomagali sobie nawzajem, poprawiali się wzajemnie. $Z$ tego powodu trudno wskazać, kto dokładnie pisał różne sekcje. Ale trzeba to podkreślić, że prawdziwymi autorami całej książki są robotnicy, którzy współdziałali przy budowie historycznego Kanału Białomorsko-Bałtyckiego imienia Stalina ${ }^{17}$.

Czy, biorąc pod uwagę te dwie deklaracje (rosyjską i angielską), nie należałoby

Na liście nazwisk w przekładzie zabrakło M. Kozakowa i A. Tichonowa. Nazwisko pierwszego zniknęło z rosyjskiego wydania 3 (z 1935 r.), co wiązało się z wcześniejszym aresztowaniem pisarza. Nazwisko drugiego figuruje we wstępie do pierwszego rosyjskiego wydania, ale brak go wśród autorów wymienionych przy poszczególnych rozdziałach; w wydaniach 2 i 3 nie ma go w ogóle. Angielski (niby-)przekład nie sygnalizuje, która rosyjska edycja była jego podstawą (zob. Ru d e r, op. cit., s. 197).

17 Note of the Method of Writing „Belomor”. W zb.: Belomor, s. IX. 
poprzestać na tym, co napisał przed półwieczem Sołżenicyn i przyjąć, że w Historii jest tylko jakiś cień autorstwa Jasieńskiego? Ale cień, jeśli już zgodzimy się na tę optyczną metaforę, może być mniej lub bardziej wyraźny. Czy zatem w całej Historii jest on wszędzie taki sam? Chyba jednak nie, skoro przy rozdziale $9 \mathrm{z}$ wersji rosyjskiej (Dobić wroga klasowego) nazwisko Jasieńskiego pada, a przy innych - nie. Angielski (niby-)przekład dzieli się inaczej niż rosyjski oryginał. Całość tworzy tutaj 10 tytułowanych „scen” (Stage I-X), z których każda zawiera tytułowane rozdziały z numeracją ciagła (ogółem jest ich 35). Rozdział 9 z rosyjskiej Historii wchodzi w skład Stage VI: The Short Karelian summer must be made the most of. Some newcomers (Krótkie lato karelskie musi być maksymalnie wykorzystane. Paru przybyszy; rozdz. XXI: Portrait of Firin (Portret Firina〉) i Stage VII: December disillusionment with progress and quality of work (Grudniowe otwarcie oczu na postęp i jakość robót). Ale w tej drugiej scenie znajdują się też rozdziały, które nie mają swojego odpowiednika w rosyjskim rozdziale 9 . Gdzie zatem jest cien Jasieńskiego? W obu anglojęzycznych „scenach” czy w ich fragmentach odpowiadających (w przybliżeniu) rozdziałowi 9? Bo trudno przecież poważnie potraktować deklarację, że wszystko pisali wszyscy lub - że podmiotem autorskim był jakiś mityczny kolektyw robotników-więźniów. Ruder dotarła do rosyjskich archiwów i odkryła maszynopisy wersji, które dokumentuja kolejne etapy w formowaniu ostatecznego kształtu całości. Ogromna większość z nich jest niepodpisana, a tam, gdzie podpis figuruje, kwestia atrybucji nie została bynajmniej rozstrzygnięta.

Dlatego amerykańska badaczka stosuje w swych dociekaniach nad autorstwem metodę polegającą na tym, by zawartość poszczególnych fragmentów dopasowywać do biografii wymienionych przy rozdziałach pisarzy. I tą drogą, analizując drobiazgowo rozdział 5 (Czekiści), wskazuje fragmenty, które prawdopodobnie przygotowywał Siergiej Ałymow, jedyny z grona 36 autorów znający obóz od wewnątrz - jako jego więzień i redaktor więziennej gazetki „Pieriekowka” ${ }^{18}$. W łączeniu biografii Jasieńskiego z zawartością rozdziałów zacznę od dość banalnej obserwacji: musiał on poznać niektóre fragmenty powstającej całości lepiej niż inne. Nie miejsce tutaj na przedstawienie metody zbierania materiałów, dość wspomnieć, iż do wizytacji Kanału przez pisarzy doszło w sierpniu 1933, gdy zdecydowana większość więźniów przerzucona już była na inne budowy. Także $z$ tego względu nie mogły się odbyć rozmowy, które w formie dialogów utrwalone zostały na kartach Historii. Tę „historię" tworzyli, nie zapominajmy tego, literaci; w procesie pisania ważne były różne dokumenty (odnotowane w bibliografiach do wydania rosyjskiego i angielskiego), nie mogły one jednak determinować narracji, która bardzo mocno trzyma się wzorców pisarstwa fikcjonalnego i wykorzystuje awangardową technikę montażu' ${ }^{19}$. Słowo „montaż” wyjątkowo dobrze pasuje do kompozycji Historii, stawiając autora w roli „montera” i zbliżając go tym samym do robotnika, którego trud miał znaleźć ekwiwalent w „montowaniu” literackiej całości. W składzie pisarzy - współtwórców tomu - znalazł się, zauważmy, teoretyk prozy i filmu, Wiktor Szkłowski. Jego nazwisko figuruje przy ośmiu rozdziałach (3: GPU, inżynierowie, projekt, 4-7, 10-11 i 13). Niewykluczone, że w każdym z nich Szkłowski uczestniczył jako „monter”, 
składający w rozdziałową całość przygotowywane przez innych części. Anna Bierzin, żona Jasieńskiego, była współautorką czterech rozdziałów, które „zmontował” Szkłowski. Wydaje mi się rzeczą psychologicznie mało prawdopodobną, żeby pisarka, przed montażem Szkłowskiego, swoich „cegiełek” do rozdziałów nie skonsultowała $z$ małżonkiem. Oboje dali swe teksty do jednego tomu, oboje uczestniczyli w tym samym wyjeździe, gdzie najprawdopodobniej oglądali i słyszeli to samo. Na tej podstawie będę twierdził, że nad wszystkimi czterema rozdziałami, przy których $\mathrm{w}$ wersji oryginalnej figuruje nazwisko Bierzin, unosi się też blady cień Jasieńskiego. Jasieński musiał żonine kawałki poznać, może je jakoś skorygował, może coś zasugerował, w każdym razie - zaangażował się w formowanie ich kształtu chyba bardziej niż w przypadku fragmentów sporządzanych przez innych współautorów rozdziału 9. Inna rzecz, że rosyjski oryginał nie pozwala kawałków pisanych przez Annę Bierzin wyodrębnić.

Najciekawszy dla historyka literatury, zainteresowanego Jasieńskim, musi być wszakże rozdział 9, ten, przy którym figuruje nazwisko pisarza. To nazwisko pada jako ostatnie na liście, obejmującej sześciu autorów; z tego miejsca, jak już wiemy, nic nie wynika, narzucił je przyjęty porządek alfabetyczny, w żadnym razie nie oddaje ono wkładu pracy i nie sugeruje jakiejś hierarchii ważności. Kiedy przeanalizujemy rozdział Dobić wroga klasowego, okaże się, iż jest on w całości tomu jednostką unikatową. Wyjątkowa przez to, że skupia się na osobie Siemiona Firina. Firin stał na czele Białomorsko-Bałtyckiego Zarządu Łagrów, a w 1933 r. objął funkcję zastępcy szefa GUŁag. Istotna jest tu jeszcze jedna jego rola - współredaktora Historii. Mówiąc krótko: w rozdziale 9 Firin zjawia się w podwójnej roli, tj. bohatera opowieści i zarazem tej opowieści współredaktora. Nie myślę, by redaktorski wkład Firina był duży czy nawet - by można go porównywać z wkładem dwóch innych redaktorów, Maksima Gorkiego i Leopolda Awierbacha. Ci dwaj byli profesjonalistami, ludźmi doskonale władającymi piórem, na ich tle językowa (i literacka) kompetencja Firina musiała wyglądać żałośnie. Firin dawał książce nazwisko i... chyba niewiele ponad to. Nie ulega kwestii, że w całym zespole przygotowującym Historię był osobą najważniejszą, najwyżej postawioną, prominentną figura sowieckiej władzy. A to musiało oznaczać, iż sylwetkę Firina w rozdziale 9 mógł przygotowywać tylko ktoś najbardziej zaufany i najbardziej ideologicznie zaprawiony. Ten ktoś pisał o Firinie-bohaterze - pod bacznym okiem Firina-redaktora i czując na plecach oddech młodego czekisty. Mechanizm wewnętrznej cenzury musiał w tym wypadku działać wyjątkowo sprawnie.

Rozdział 9 rozpoczyna się od telegramu z grudnia 1932, który do zastępcy szefa Białomor GUŁagu, Jakowa Rapaporta, wysłał szef OGPU ${ }^{20}$, Gienrich Jagoda. W telegramie wyrażone zostało zaniepokojenie niewypełnianiem norm przy budowie Kanału i znalazło się wezwanie do wzmożenia dyscypliny pracy (,trud-discypliny”). Tekst kończy się zobowiązaniem Rapaporta do przedstawienia szczegółowych informacji o robotach, które pozostaja jeszcze do wykonania, wraz z kalendarzem ich realizacji. Całość zamyka kategoryczne żądanie: „Dane powinny być w Moskwie 1 stycznia [1933]". 
Kolejna część rozdziału, zatytułowana Trzydzieści trzy lata życia, zaczyna się scenką na stacji:

Dwa tygodnie po tym telegramie, w grudniowy śnieżny dzień, pociagg leningradzki wysadził w Miedwieżjej Gorie nową grupę pasażerów. Człowiek w szarym wojskowym płaszczu jako pierwszy zszedł na peron.

Scenkę stacyjną zamyka akapit zbudowany z dwóch pytań, które mógł stawiać sobie czytelnik: „Kim jest ten człowiek? Jakie losy przywiodły go na Biełomorstroj?” I w ten oto sposób zaczyna się kluczowa część rozdziału, odtwarzająca retrospektywnie 33 lata życia Firina. Część tę zamyka spotkanie Jagody z Firinem i decyzja o wysłaniu młodego czekisty na budowę Kanału.

Następny podrozdział nosi tytuł Pierwsze kroki Firina i stanowi fabularną kontynuację poprzedniego. Pokazuje on Firina w działaniu, już na budowie Kanału, przede wszystkim w scenach inspekcji i rozmów $Z$ zatrudnionymi. $Z$ rozmów tych wyłania się problem, który staje się przedmiotem dociekań zarówno Firina-bohatera, jak i narratora kolejnego podrozdziału. Tytuł podrozdziału ma formę pytania: Co to takiego tufta. „Tufta” jest słowem z rosyjskiej gwary więziennej, oznaczającym oszukiwanie przez zawyżanie raportów i liczbowych wyników pracy osadzonych. Jerzy Pomianowski, tłumacząc Archipelag GUŁag, zastępował to słowo „fuchą" lub „partanina” ${ }^{21}, \mathrm{i}$ - stosownie do tego - pisał o posługujacych się „tufta” jako o „partaczach”. Dwie kolejne części rozdziału dotyczą kwestii „tufty”, rozpowszechnionej na budowie. To Ukrywacz nierobów i Przodowniku! ty im przeszkadzasz ${ }^{22}$. Zwieńczeniem całości poświeconej „tufcie” jest rozdział Odpowiedź na tuftę. Partie dotyczące „tufty” oddał Sołżenicyn, ironicznie parafrazując wypowiedzi Firina-bohatera:

Kontrola wykryła, że - gdyby wierzyć waszym sprawozdaniom - to już pa r o k r o tn i e wykopano cała przewidzianą w planie ilość gruntu! - a Kanał wciąż nieukończony! Nieudolni kierownicy robót zasypują wądoły nie szutrem, tylko lodem! A wiosną lód topnieje i woda przerwie tamy! Nowe hasło dla kultwychu: „Fucha - to groźna broń kontrrewolucji” (a w dziedzinie fuchy knajacy wiodą prym: ten lód zamiast ziemi - to na pewno ich pomysł, poznaje bez trudu!). [...] Fucha - to próba pokrzyżowania wszystkich produkcyjnych i wychowawczych planów GPU - oto czym jest ta straszliwa fucha! Fucha to grabież własności socjalistycznej! - oto czym jest fucha ${ }^{23}$.

Następny podrozdział kieruje uwagę czytelnika na pracujące przy budowie Kanału kobiety. Rozdział nosi tytuł Rozkaz o kobiecej wstydliwości i zaczyna się od przytoczenia w całości dokumentu podpisanego przez Firina, a datowanego na 8 II 1933: O niedostatkach pracy kulturalno-wychowawczej wśród kobiet i n niezbędnych środkach dla poprawienia tej pracy. Dokument wymienia listę błędów popełnianych w polityce wychowywania kobiet przez pracę i kończy się rozkazami, których aplikacja ma zagwarantować cel resocjalizacyjny: przygotowanie więźniarek do powrotu - jako uczciwych i uświadomionych obywatelek - do „rodziny ludzi pracujących Związku Sowieckiego". Dopełnienie tego podrozdziału stanowi indywidualna historia jednej z tych kobiet, Anny Jankowskiej, której konflikty z prawem skończyły się

21 Zob. Sołżenicy n, op. cit., s. 61, przypis.

22 W oryginale pada słowo „udarnik”, pochodzacy od czasownika „udarit'” ('uderzać', 'wybić', 'szturmować). „Udarnikiem” nazywano robotnika przekraczającego normy. Nieco później w tej roli pojawił się rzeczownik „stachanowiec” (utworzony od nazwiska górnika Aleksieja Stachanowa). 
skierowaniem na budowę Kanału. Na budowie bohaterka przechodzi przełom, uczy się uczciwie pracować, pomaga jej w tym wychowawczyni, która 4-godzinną rozmową i podawanymi przykładami doprowadza swą rozmówczynię „do łez”. Tekst jest przerwany zdjęciem, na którym widać kobiety pchające taczki. Podpis pod fotografia obwieszcza: „Brygady kobiece współzawodniczyły z nacmienowskimi”. Podpis ten zapowiada przejście do ostatniej części tego podrozdziału, zatytułowanej Rozkaz nr 55. Uwaga $z$ kobiet przenosi się teraz na pracujących przy budowie „nacmienów”24, czyli przedstawicieli mniejszości narodowych - więźniów pochodzących z Kaukazu, Syberii, ale przede wszystkim z rosyjskiej Azji Środkowej. Granica między tym a kolejnym podrozdziałem ma charakter tylko formalny, sygnalizuje ja tytuł Przełom zabezpieczony, wciąż bowiem pozostajemy w kręgu spraw, które wywołał Firinowski „rozkaz nr 55”, tzn. wzmożenia pracy ideologicznej i wychowawczej z przedstawicielami mniejszości narodowych.

Zamyka całość podrozdział zatytułowany Zestawienie rachunkowe. Czytelnik znajduje w nim scenę zbudowaną paralelnie do tej, która rozdział otwiera. Widzimy po raz ostatni Firina, ale już w innej roli i w innym miejscu: na budowie kanału Wołga-Moskwa, w przemówieniu na zjeździe pracowników „finoddziału”. Finoddział, czyli oddział finansowy, to sekcja administracji zajmująca się sprawozdawczością i finansami budowy (a wchodząca w skład OGPU). Do zadań tego oddziału, który obsługiwał budowę Kanału Białomorsko-Bałtyckiego, należało skrupulatne podliczenie wszystkich kosztów inwestycji. Wgląd w te koszty ma również czytelnik. Na Kanał wydano ponad 100 mln rubli (dokładnie: 101316 611). Ponad 17 mln wymagały roboty zlecone innym przedsiębiorstwom. $Z$ pozostałych 74 mln poszło na utrzymanie pracujących ponad 1/3 tej kwoty. Na zjeździe Firin mówił, że Kanał Białomorsko-Bałtycki zmienił pracujących przy nim ludzi, także tych $z$ oddziału finansowego:

Finoddział OGPU zdołał [...] podciągnąć swoją pracę w ogólnym systemie naszych organów, zdołał w takim stopniu rozbić szeroko rozpowszechnione wyobrażenie o szeregowym robotniku jako o oschłym kanceliście, którego krąg interesów ograniczony jest do kulek w liczydle i księgi buchalteryjnej, - finoddział zdołał swoich robotników na tyle podciągnąć do poziomu przodujących bojowników naszych organów, że dziś finoddziałowcy są wśród czekistów równoprawnymi i przez wszystkich cenionymi towarzyszami.

Ostatnie zdanie w rozdziale należy do narratora: „Przed mówcą siedzieli towarzysze, którzy dopiero pół roku temu podbili ostatni bilans sprawozdania finansowego Biełomorstroja".

Gdzie w rozdziale 9 wniósł swój wkład Jasieński? Którą część pisarsko przysposobił do „montażu”? Skłonny jestem sądzić, że przy rozłożeniu zadań pomiędzy szóstką współautorów istotne było kryterium ważności tematu. W rozdziale traktującym o „dobiciu wroga klasowego” najważniejszą osobą jest ten, kto kampanią pacyfikacyjną ma zawiadywać na miejscu, tj. Siemion Firin. Kampania kończy się pełnym zwycięstwem, bo przecież ostatni podrozdział jest świadectwem tego, że cel został osiagnięty, kanał - przekopany, a tysiące więźniów może znaleźć zatrudnienie na nowych budowach. Tego „zwycięskiego” podrozdziału końcowego nie można

24 To typowy dla sowieckiej nowomowy „zlepek”, utworzony ze słów „nacyonalnoje mieńszynstwo” 'mniejszość narodowa'. 
było, co oczywiste, zlecać Jasieńskiemu, jedynemu w całym kolektywie pisarskim człowiekowi z niesowieckim rodowodem. Tom pierwszego wydania Historii, przypomnę, trafił najpierw do rąk delegatów na tzw. Zjazd Zwycięzców. O zwycięstwie przy budowie Kanału mógł pisać tylko ktoś o nieskazitelnie czystym życiorysie, bo przecież miał swoim pisaniem wbijać w dumę tych, którzy przybyli na XVII Zjazd WKP(b). Toteż $\mathrm{z}$ listy potencjalnych autorów owego podrozdziału wykreśliłbym nazwisko Jasieńskiego.

Podobnie postąiłłbym $z$ listą autorów typowanych do podrozdziałów pierwszego i drugiego (Trzydzieści trzy lata życia i Pierwsze kroki Firina). Oba wymagały pisarzy doświadczonych, sprawdzonych, o nienagannym kręgosłupie ideologicznym. Nie wykluczam, że najlepiej mogła to zrobić jedna osoba, ale tym bardziej nie widziałbym tutaj zatrudnienia dla Jasieńskiego, człowieka z Polski, z kraju, który Firin poznał dwukrotnie (w 1918 i 1920 r.) - jako zajadłego wroga jego robotniczej ojczyzny. Część poświęconą kobietom z budowy Kanału i historię Anny Jankowskiej najchętniej związałbym $z$ nazwiskiem Wiery Inbier. Skoro bowiem w zespole opracowującym rozdział 9 była tylko jedna pisarka, naturalne wydaje mi się, że Rozkaz o kobiecej wstydliwości został na nią właśnie scedowany. Kobiety, przypomnę, znalazły się w opowiadaniu w tej samej grupie co przedstawiciele mniejszości narodowych. Do jednych i do drugich odnosiły się rozkazy Firina wydane dzień po dniu 8 i 9 II 1933. Łączyła te grupy fotografia z podpisem, który mówił, iż zespół kobiecy dorównać może zespołowi złożonemu $z$ „nacmienów”. Dodać trzeba, że cały rozdział poprzedza inna fotografia, $z$ podpisem: „Sztandar sztabu współzawodnictwa zdobyty przez brygadę kobiecą" W tekście Przełom zabezpieczony pojawia się podobne w swym przekazie zdjęcie. Figuruje na nim, jak głosi podpis, „Nacmien-przodownik, Birkimbasja, ze sztandarem kolektywu pracy". W zespole pisarskim przygotowującym rozdział 9 nie było żadnego przedstawiciela mniejszości narodowych, kogoś, komu zlecić by można partie o „nacmienach” na podobnej zasadzie jak partie kobiece - Wierze Inbier. Był wszakże pisarz, który kulturę ludów Azji Środkowej poznał i tę znajomość, krótko przed wyprawą nad Kanał, literacko udokumentował. To Bruno Jasieński, wyjeżdżający w sierpniu 1933 na budowę Biełomoru jako autor świeżo opublikowanej (i napisanej po rosyjsku) powieści Człowiek zmienia skórę ${ }^{25}$.

Ruder nie zdołała ustalić, wedle jakich kryteriów dobrano zespół 120 pisarzy, którzy udali się na wizytację świeżo otwartego Kanału. $Z$ pewnością jednak jakieś zasady kwalifikacyjne zostały tutaj zastosowane, coś musiało przemawiać za tym czy innym kandydatem na wyjazd; i przeciwnie: były z pewnością okoliczności, które działały dyskwalifikująco. Nie musiały to być wcale kryteria wspólne dla wszystkich i wewnętrznie spójne. Kiedy czyta się wykaz 66 zidentyfikowanych osób, trudno przyjąć, że w doborze uczestników znalazł odzwierciedlenie jakiś ranking 
poziomu artystycznego. Bo są na liście nazwiska wielkie i doskonale znane, ale też - kompletnie nic nie mówiące. Znaczące jest to, że badaczce udało się ustalić tożsamość tylko 66 osób. Kim byli pozostali? Brak najmniejszych wzmianek w sowieckich źródłach (relacjach prasowych i zachowanych dokumentach) o 54 uczestnikach wyjazdu może świadczyć, że stanowili oni literacki plankton.

Podobne watpliwości rodzą się, gdy chcemy ustalić, co zadecydowało, iż ze 120 uczestników kosztownego wyjazdu pracą artystyczną miało zrewanżować się nieco ponad 30. Autorów rozdziałów jest wprawdzie 36, wiemy jednak, że Gorki pisał, choć nie pojechał, Szkłowski (prawdopodobnie) „montował”, a odwiedził Kanał przy innej okazji. Ale także tutaj trzeba przyjąć, iż twórcy Historii zostali jakoś wyselekcjonowani spośród tych, którzy Kanał wizytowali. Coś liczyło się na korzyść wybranych, coś innego - stanowiło dla odrzuconych szkodliwy balast. Myślę, że Jasieński musiał przedstawić przed wyjazdem listy uwierzytelniające, mieć argumenty na tyle mocne, że dawały mu miejsce w zespole osób udających się nad Kanał, a potem - zapewniły udział w elitarnej ekipie piszącej Historię. Nie sądzę, aby na korzyść Jasieńskiego przemawiał jego polski dorobek poetycki. Powieść Pale Paryż chyba także nie zapewniała najwyższych notowań. To samo powiedziałbym o rosyjskim Balu manekinów. Wydaje mi się, że legitymacją uprawniającą do wyjazdu stała się powieść o budowie kanału nawadniającego w Tadżykistanie. Historia, która mówiła o tym, że „nowe obowiązki i nowe perspektywy wymagają od człowieka radykalnej przebudowy". Porzucenia starej skóry. Jasieński pisał sentencjonalnie: „Stara skóra na tyle się zrosła, że niekiedy trzeba odrywać ją razem z mięsem" ${ }^{26}$. Na budowie Kanału Białomorsko-Bałtyckiego dokonywał się podobny proces przemiany ludzi, oficjalnie znany jako „pieriekowka”. Jasieński w powieści o nawadnianym Tadżykistanie dowiódł, że ma wszelkie dane, by w zimnej Karelii „przebudowę” więźniów dostrzec i gorąco poprzeć zastosowane tam metody wychowawcze. Tym bardziej że wśród budujących mógł pisarz spotkać ludzi z Azji Środkowej, wcześniej zaprawionych w wielkich robotach hydrotechnicznych ${ }^{27}$.

W rozdziale 9 są trzy fragmenty, gdzie zjawiają się więźniowie z Azji Środkowej. Pierwszy, najkrótszy, to scenka wstawiona do podrozdziału Pierwsze kroki Firina. Przybyły z Moskwy Firin odwiedza kolejno baraki i - jak czytamy:

po wyrazie jego twarzy trudno było osądzić, czy podoba mu się tu, czy nie. Także w słabo ogrzanych barakach kobiecych i nacmienowskich, których stan sanitarny był poniżej wszelkiej krytyki [...] nie wyraził żadnego niezadowolenia.

Kolejny akapit zaczyna się słowami „Raz tylko”, po których czytelnik mógłby się spodziewać powiadomienia o tym, że jednak coś Firina w wizytowanym obozie mocno poirytowało. Okazuje się, że nie poirytowało, lecz jedynie „zainteresowało”. Zainteresowała go mianowicie scenka w ambulatorium, a dokładniej - „mimiczna rozmowa lekpoma z pacjentem-Uzbekiem”. „Lekpom”, czyli pewnie jakiś pomocnik lekarza (,liekarskij pomoszcznik”, felczer), najwidoczniej nie rozumie słów pacjenta, 
próbującego opisać swoje niedomaganie „krasomówczymi gestami”. To prowokuje Firina do postawienia badającemu pytania: „Czy rozumiecie, co mu dolega?” Na co pada odpowiedź:

Oni są narodem nieświadomym i rozmówić się w zrozumiałym języku nie umieją. Mimo to dogadujemy się. Przy pewnym doświadczeniu, jeśli lekarz ma wprawne oko, diagnozujemy na podstawie zewnętrznych oznak.

Drugi fragment z udziałem „nacmienów” znajduje się w tym samym podrozdziale nieco dalej. Firin wchodzi do baraków, gdzie - jak się dowiadujemy - odbywa „dziwne rozmowy”:

- Witajcie!

- Witajcie!

- Jesteś z Fergany?

- Z Fergany.

- Widzę. Byłem w waszych stronach. Jak pracujesz?

- Pracujemy, naczelniku.

- Dobrze pracujesz?

- Dobrze pracujemy, naczelniku.

- Nie, ty źle pracujesz.

- Źle pracujemy, naczelniku.

- A ty skąd jesteś?

- Nie rozumiemy po rosyjsku.

Scenkę zamyka narracyjny komentarz:

W barakach u nacmienów było brudno i ciemno. Na narach ${ }^{28}$ siedzieli Uzbecy, Baszkirzy, Tadżycy, Jakuci, najbardziej zacofani ludzie na budowie, napiętnowani w gazecie „Pieriekowka” jako nieroby.

Niedobra sytuacja, zarysowana w obu scenach, znajduje swój finał nie w irytacji Firina, lecz w - rozkazie nr 55, który czytelnik poznaje w obszernym omówieniu:

Czy myślicie o nacmienach? - pytał rozkaz. Sądzić wolno, że mało albo w ogóle nie myślicie. Rozejrzyjcie się wokół siebie. Wśród nacmienów nie ma wychowawców. Pomieszczenia są złe. I, nie przyglądając się specjalnie, znajdziemy na odzieży i w pościeli nacmienów wszy. Tak, wszy, tego maleńkiego wroga, którego brakiem chlubimy się na naszej budowie. A wy wpuściliście go, hodujecie go. Mało tego, u nas w obozach do baraków nacmienów wsączają się mułłowie. Mułłowie czytają Koran, więźniowie idą do pracy zamiast mułłów, mułła daje rady, mułła uczy więźnia. Tak że wy, towarzysze, robicie z obozów medresęe29. Lekarze nie znają języka, leczenie odbywa się „po omacku”. To szowinizm, to odnoszenie się do ludzi - jak do ludzi „drugiego”, gorszego gatunku.

Śmielej, przyjaciele, mówi rozkaz, śmielej obchodźcie się z życiem, a niezwykłe krainy otworzą się przed wami.

Zaraz po tych słowach zaczyna się podrozdział Przełom zabezpieczony, formalnie nowa część, ale w planie tematycznym - część pokazująca rozwiązanie problemów, na które zwracał uwagę „rozkaz nr 55”. Zanim przejdę do tego podrozdziału, słówko o angielskim przekładzie i o tłumaczeniowych odpowiednikach obu przywołanych scen $z$,nacmienami”. Przeszły one w przekładzie do rozdziału XXII: Firin comes to investigate (Firin przyjeżdża, by poprowadzić dochodzenie); zmiany są 
nieliczne, ale dość znaczące: Uzbeka bada „lekarz” (a nie żaden „pomocnik lekarza”), badanie odbywa się nie w „ambulatorium”, lecz w „klinice [clinic]”30.

Podrozdział Przełom zabezpieczony pokazuje, jak zmienia się sytuacja, która trafnie zdiagnozował Firin. Zwieńczeniem starań o włączenie „nacmienów” do współzawodnictwa pracy jest pierwszy ogólnoobozowy zlot. Ale wcześniej władze musiały podjać działania, by przełamać nieufność i lęk i by wzniecić entuzjazm więźniów. Efekty zdumiewały:

Kanałoarmista czwartego bojowego odcinka, Jakub Chasanow, ogłosił huraganowy szturm skały. Kruszył i kruszył skałę. Bez zmiennika - sam. Wbiegał do baraku na 15 minut, żeby się rozgrzać, i znowu kruszył. Pracował rano, w dzień, wieczorem i nocą. Kiedykolwiek i gdziekolwiek by się go spotkało - kruszył skałę. Potem zebrał brygadę szturmową [złożoną z trzydziestu nacmienów i nauczył ich pracować i kruszyć skałę.

„Nacmienów” długo paraliżował strach przed kurzawką. Wzbudzającą obawy kurzawką zajęła się obozowa prasa, a o sprawie stało się głośno wśród więźniów:

„Idźcie na bój z najstraszniejszym wrogiem - kurzawką”, pisze w gazecie oddziału łagkor-trzydziestopiątkowiec, Karpusza, i sam nie wychodzi z wykopu. Odtąd na wydartej z notesu liniowanej ćwiartce składa swoje korespondencje, niezgrabne, ale zwięzłe i dokładne, jak wojskowy meldunek.

W nacmienowskim kolektywie wielu kanałoarmistów zaczęło pokonywać przesądy. Natknąwszy się na kurzawkę, rzucają łopaty i patrzą ze zdziwieniem. Boją się kurzawki jak diabła. Jeśli tylko pojawiała się kurzawka, nacmieni zaraz przesuwają się z przodowników do niewypełniających normy ${ }^{31}$.

Rozwiązanie okazało się łatwe: starczyło tam, gdzie występowało zagrożenie kurzawką, wymieszać „nacmienów” z „kurzawkowcami”32 z innych brygad:

Obok chodzi z książeczką łagkor i układa doniesienie o zwycięstwie nad kurzawką i ludzkim przesadem.

Praca idzie po nowemu. Popatrzcie na nacmienów. Zrozumcież, tu wszystko dla nich było obce i dzikie: przyroda, język, żywność, odzież. Słońce, jak powiedział jeden z nich, ,jakby przez owcze runo” (wojłok). On nie czuje tego cudzego słońca, chociaż latem ono pali i dorównuje przyzwoitemu słońcu. On marznie.

Na pierwszym ogólnoobozowym zlocie przodowników-,nacmienów” „w ciasnych rzędach siedzą Turcy, Uzbecy, Ormianie, Kozacy, Tatarzy. Rozbudziło ich jedno i jedno dało im ojczyznę - to, co nazywa się socjalizm”. Życie przedstawicieli mniejszości narodowych zmieniło się nie do poznania:

Oni [tj. przedstawiciele mniejszości narodowych] są teraz w barakach i namiotach: wśród swoich,

Zob. Belomor, s. 250. Odpowiednik „dziwnych rozmów [strange conversations]” znajduje się na s. 252. W tłumaczeniu chciałem oddać sowiecką nowomowę. „tagkor" to „tagiernyj koriespondient”, czyli „korespondent obozowy”. „Trzydziestopiątkowiec” to więzień osadzony na podstawie artykułu 35 sowieckiego kodeksu karnego. Artykuł ten brzmiał następująco: „Wydalenie poza granice ZSRR, poza granice RSFSR lub poza granice miejscowości, $z$ obowiązkowym osiedleniem lub zakazem zamieszkiwania w innych miejscowościach lub też bez tych ograniczeń może być stosowane przez sąd na okres nie dłuższy niż pięć lat w stosunku do tych osób, które dokonały przestępstwa, a pozostawienie ich w danej miejscowości uważane jest przez sąd za niebezpieczne dla społeczeństwa. Jeśli określone środki ochrony społecznej ustalone sa jako dodatkowe do kary pozbawienia wolności, to początek określonego przez sąd okresu tychże odnosi się do momentu odbycia kary wiezienia". Chodzi o tych, którzy nie boją się kurzawki. W oryginale jest "ptywunszczik”, co stanowi formację utworzoną ze słowa „ptywun” (oznaczającego kurzawkę) i formantu „-szczik”. 
w swoim cieple i w swojej przestrzeni. Wydzielono im osobne kotły i okienka do wydawania żywności, a dla słabowitych urządzono osobną stołówkę, dano im wychowawców-rodaków, ściengazetki w ojczystym języku, mnogość możliwych kółek zainteresowań, głośno czytane są im gazety.

Podrozdział zamyka przytoczenie meldunku Firina: „zloty przodowników, kobiet, nacmienów odbyły się prawidłowo. Przełom zabezpieczony. Nacmieni przyłączają się do budowy". Dwa słowa o odzwierciedleniu całej tej długiej partii w angielskim przekładzie: do tłumaczenia nie przeszła ani jedna linijka!

Posłużyłem się obfitymi przytoczeniami z rozdziału 9 Historii, bo sądzę, że zacytowane zdania składał Jasieński. Jego widziałbym jako autora scenki w ambulatorium, gdzie lekarz nie potrafi porozumieć się z pacjentem Uzbekiem, jego także uznałbym za twórce „dziwnych rozmów”, jakie z przedstawicielami mniejszości narodowych przeprowadził Firin. A historia o „rozkazie nr 55” i o jego przykładnym wypełnieniu stanowiła, moim zdaniem, główny wkład Jasieńskiego w kompozycję rozdziału 9. Powtarzam, nie mam na to żadnych niezbitych dowodów, obracam się w kręgu domysłów i zbieżności literackich. Taką zbieżność widzę w chwycie wypróbowanym w powieści o Tadżykistanie, a odgrywającym kluczową rolę $\mathrm{w}$ analizowanych teraz fragmentach Historii. Chodzi o konsekwencje wynikające $z$ bariery językowej. Przypomnę, że główny bohater tadżyckiej powieści jest Amerykaninem, któremu w pracy pomaga tłumaczka. Inżynier Jim Clarke przyjeżdża do Rosji Sowieckiej, bo jego kraj przeżywa kryzys i odczuwa „nadprodukcję technicznej inteligencji”. Wielu komentatorów porównywało Clarke’a z Jasieńskim, nikt dotąd nie zwrócił uwagi, że fikcyjny bohater przyjeżdża do Moskwy pociagiem nie z Leningradu, lecz... z Niegorełojego ${ }^{33}$. Niegorełoje to stacja na granicy z Polska, tu, podróżując $z$ zachodu na wschód, trzeba było zmienić pociagg (w odwrotnym kierunku przesiadka odbywała się w polskich Stołpcach). W roku 1929 Jasieński przyjechał do Rosji Sowieckiej przez Leningrad, omijając szerokim łukiem swą ojczyznę. Aby wzmocnić więzy fikcyjnego inżyniera Clarke’a z sobą, pisarz posłał swego bohatera drogą wiodąca z Ameryki przez Polskę.

W Tadżykistanie inżynier Clarke wielokrotnie natrafia na mur niezrozumienia. Przenośnie i dosłownie. Warto przypomnieć zabawną scenę z początku powieści. Clarke, poruszony buntem robotników, którzy nie dostawszy machorki, odmawiają wyjścia do pracy, postanawia przemówić. Przemawia, ale - jak się później okazuje - jego słowa tłumaczka zamienia na swoje. I to właśnie jej słowa, nie zaś inżynierskie, trafiają do zbuntowanych. Przemiana inżyniera idzie $\mathrm{w}$ parze $\mathrm{z}$ nauką języka (i przy okazji - z zacieśnianiem więzi z komsomołką-tłumaczką). Dlatego przełom otrzymuje w powieści swój ekwiwalent językowy: odmieniony w warunkach sowieckiej budowy Clarke zaczyna porozumiewać się ze swoim otoczeniem po rosyjsku. Obcość sprzężoną z bariera językową wykorzystał Jasieński także do nakreślenia sylwetki wroga. Inżynier Murri (zdemaskowany na końcu jako imperialistyczny agent) potrzebuje w pracy tłumacza, choć - z czym się krył, a co ujawnia śledztwo - doskonale umie posługiwać się językiem rosyjskim.

Pisarze układający narrację $\mathrm{w}$ Historii musieli uporać się z fundamentalną przeszkodą, która brała się $\mathrm{z}$ tego, że cała niemal materia zdarzeniowa stanowiła w trakcie wizyty zamkniętą przeszłość, trzeba ją było zatem zrekonstruować, a właś- 
ciwie - stworzyć. I tu z całą pewnością liczyło się pisarskie doświadczenie, podpowiadające, w jaki sposób ze strzępów wiedzy i z migawkowych wrażeń z krótkiej wycieczki ułożyć opowiadanie o zdarzeniach składających się na blisko dwuletnie zmagania więźniów. Jasieński, wyjeżdżając na wizytację Kanału, zabrał ze sobą spory bagaż gotowych schematów, które pomagały w literackim opracowywaniu nowego tematu. Komponując sekwencję scen dotyczących kurzawki, mógł pisarz odwołać się do tego, co wcześniej zawarł w powieści, w partiach odnoszacych się do „świętej góry” Kata-Tag ${ }^{34}$. Z fragmentów rozdziału 9 wynika, że „nacmieni” boja się „kurzawki”, nie wiemy jednak - dlaczego. Strach wiąże narrator z „przesądami”, tuż przed opowieścią o poskromieniu kurzawki czytelnik dowiaduje się o intensywnej pracy „kółek antyreligijnych”. Paniczny lęk przed kurzawką miał zapewne swe źródło w jakimś przesądzie, podobnym prawdopodobnie do tego, który chronił przed łopatami budowniczych „świętą górę” Kata-Tag 35 .

Tytułowa formuła $z$ powieści może być zatem odnoszona do samego Jasieńskiego. W Rosji Sowieckiej, po przyjeździe w maju 1929, rozpoczął on proces intensywnego przeobrażania się. Zaczął pisać po rosyjsku, mówić po rosyjsku, może też myśleć w tym języku. Tę przemianę świetnie ilustrowała fikcyjna biografia inżyniera Clarke’a. Metafora zmiany skóry jeszcze mocniej wiąże losy fikcyjnego inżyniera i Jasieńskiego. Metafora ta ma jednak w powieści szersze odniesienie, charakteryzuje bowiem proces, któremu ulega znaczna część zatrudnionych przy budowie tadżyckiego kanału. Pracują tam ludzie wolni (przynajmniej tak przedstawia ich Jasieński), jednak ważna rola w całym procesie resocjalizacji przez budowę spoczywa na organach władzy i represji. Zmiana skóry każe myśleć o jakimś zabiegu chirurgicznym i to rozwinięcie medyczne zjawia się, gdy pisarz charakteryzuje działanie GPU. O tym działaniu mówi on ustami nowo przybyłego na budowę inżyniera Kirsza, który w rozmowie ze zdymisjonowanym inżynierem Niemirowskim tak wspomina swą trudną przeszłość:

Aby zrozumieć to wszystko, musiałem wyjść na kilka lat z potoku rozrzutnej nowej rzeczywistości i zastanowić się nad nią na uboczu, w otoczeniu sztucznej ciszy i samotności. Naturalnie, izolacja sama nie przekonywa. Potrzebna jest ludzka pomoc. Tę pomoc znalazłem i pan ją znajdzie tam, gdzie najmniej pan się jej spodziewa - u ludzi, których sama nazwa wydaje się panu teraz nienawistną i straszną, ponieważ od częstego powtarzania stała się ona dla nas mitem i nasza niska wyobraźnia oporządziła go wszystkimi akcesoriami Grand Guignolu. Mówię o GePeU. Spotkałem tam ludzi, którzy odnieśli się do mnie nie jak wróg odnosi się do wroga, a raczej jak lekarz odnosi się do psychicznie chorego: $\mathrm{z}$ wielką cierpliwością i wielką spostrzegawczością. Mogliby nie tracić na mnie tyle czasu, a wlać mi po prostu

Ibidem, Księga 2, s. 205-214. Rzecz ciekawa: przekład powieści z 1934 r. bierze niemal całkowicie w nawias świętość góry. Czytamy tu mianowicie objaśnienie podawane „cudzoziemskiemu pisarzowi”: „A więc problem Kata-Tag - to problem gruntu. Do tego, aby woda nie przeciekała i nie podmywała usypanej grobli, niezbędny jest stały grunt. Tymczasem akurat w tym miejscu mamy sypki grunt. Nazywany tutaj "popiołem grobowym". Kolorem i swą sypkościa przypomina rzeczywiście popiół" (s. 205). W późniejszym przekładzie powieści, z r. 1961 (s. 526-527), w zacytowanym fragmencie wypowiedzi, kierowanej do francuskiego pisarza, pada jeszcze jedno zdanie: „Zapomniałem [...] panu powiedzieć, że sama góra Kata-Tag uważana jest przez ludność za świętą”. Po kwestii Francuza (,Tak? To ciekawe!") następuje dłuższa wypowiedź Morozowa, gdzie mowa jest o zlokalizowanym na szczycie góry cmentarzu i o agitacji mułłów, ostrzegających przed naruszeniem świętości miejsca.

35 Działania Murriego-Baily'ego powodujące osunięcie się góry są w powieści rozpaczliwą próbą zahamowania budowy kanału. Dramatyczne wydarzenia kończą się jednak zdemaskowaniem angielskiego szpiega i pomyślną naprawa uszkodzeń. 
do rannej kawy cyjanku potasu, jako nieuleczalnemu. Zamiast tego prowadzili ze mną długie dyskusje, rozbijając krok za krokiem moje chwiejne argumenty. „Oni” nie mieli potrzeby chytrego manewrowania, na „nich” pracował olbrzymi kraj, dając im w ręce argumenty w dziesięciokrotnej ilości. Każdy nowy wielki piec, każdy nowy olbrzym przemysłowy, puszczany w ruch, zbijał me argumenty, jak nieomylne dalekosiężne działa. [...] I kiedy pewnego rana powiedzieli mi, że mogę pójść na jedną z czerwonych kropek, które zapłonęły (w czasie mej nieobecności) światłem elektrycznym na mapie mego kraju, nie potrzebowałem ani się przyłączać, ani przyswajać sobie tych przepuszczonych pięciu lat, udałem się prosto na rusztowania budowy. Nie sądzę, abym cośkolwiek na mej izolacji stracił. Straciłem jakieś dwa lata na niepotrzebną obronę $\mathbf{z}$ góry przegranej pozycji, ale wygrałem całą epokę....

Kirsz, jak łatwo się domyślić, mówi o swoim uwięzieniu i o zbawiennym wpływie reedukacji przez „izolację”. Wychowywać można także inaczej, a mianowicie przez kolektywną pracę: „Gdybyśmy nie wychowywali robotników w trakcie samej pracy, to $\mathrm{z}$ tym ludzkim materiałem, $\mathrm{z}$ którym zaczęliśmy budować, na pewno nie bylibyśmy w stanie urzeczywistnić ani jednej budowy"37. Jasieński w powieści o Tadżykistanie pokazywał dwie instytucje, w których „człowiek zmienia skórę”. W sierpniu 1933 pisarz wyjechał do miejsca, gdzie resocjalizacyjne siły budowy i „izolacji” zostały połączone. Wyższość nowej praktyki oddawał nowy język: w Tadżykistanie „zmieniano skórę” („leczono” dwiema metodami), w Karelii dokonywano „przekuwania”.

Daleki jestem od tego, by, biorac pod uwagę wszystkie przywołane tutaj okoliczności, mówić o samodzielnym autorstwie. Kawałki ułożone przez Jasieńskiego zapewne czytała i poprawiała jego żona, Anna Bierzin, potem robili to inni współautorzy rozdziału 9. Ktoś (Korniel Zielinski?) kawałki te obrobił i zmontował. Poprzestanę zatem na wygodnej metaforze, która wprowadziłem w tytule, i powiem, że w rozdziale 9, w trzech przeanalizowanych urywkach, widzę cień Jasieńskiego wyraźniejszy niż gdziekolwiek indziej.

Abstract

WOJCIECH TOMASIK Kazimierz Wielki University, Bydgoszcz

JASIEŃSKI'S SHADOW A BIOBIBLIOGRAPHICAL CONTRIBUTION

In Bruno Jasieński's literary output there is a piece which remains unnoted in biographical papers and bibliographies, namely a volume published in Moscov in the year 1934 entitled Беломорско-Балтийский канал имени Сталина: История строительства, 1931-1934 г2. (Belomor: An Account of the Construction of the Great Canal Between the White Sea and the Baltic Sea) edited by Maxim Gorky, Leopold Auerbach, and Semen Georgievich Firin. Jasieński is found among the group of 120 writers who came to sightsee the White Sea-the Baltic Sea Canal build with the hands of prisoners, and subsequently entered the group of 36 men of letters invited to prepare a collective work documenting the visit. The work's content is preceded by a list of contributors. Jasieński is found among the co-authors of chapter 9: To Kill Class Enemy in which the Polish writer probably prepared the parts the protagonists of which are Central Asia prisoners. Before his travel to the construction Jasieński published a novel in Russian about the building of a canal in Tajikistan entitled Man Changes His Skin. With the novel he might have won favor of Soviet authorities which made him responsible for preparing the fragments of chapter 9 about the ideological maturation of builders from national minorities. It cannot be excluded that Jasieński participated also in the parts prepared by Anna Berzin, at that time the writer's wife. 